\title{
Performance of Sugar Beet (Beta vulgaris L.) Cultivars under the Intercropping with Clover in Arid Land Conditions
}

\author{
Ghassan H. Edrees, Fathy S. El-Nakhlawy and Saleh M. Ismail \\ Arid Land Agriculture Department, Faculty of Meteorology, Environment and Arid Land \\ Agriculture, King Abdulaziz University, Jeddah, Saudi Arabia \\ ghassanedrees983@gmail.com
}

\begin{abstract}
This investigation was carried out at Hada AL-Sham Agricultural Research Station, KAU to study the behavior of three sugar beet cultivars (Farida, Dita and Heros) under three intercropping systems (sugar beet sole, 1sugar beet: 2 clover and 1sugar beet:3 clover rows) during 2016-208 seasons. Intercropping systems produced higher root and sucrose yield/ha more than sole plantation. In addition, Farida $\mathrm{cv}$ was the highest in root and sucrose yield compared with the other cultivars. Farida cv under the1sugar beet: 3clover intercropping system produced the highest sucrose yield/ha ( $4.45 \mathrm{t}$ and $7.04 \mathrm{t} / \mathrm{ha}$ in the 1 st and 2 nd seasons, respectively).
\end{abstract}

Keywords. Chlorophyll, Cultivar, Intercropping, Sucrose, Sugar beet

\section{Introduction}

Sugar beet is the second sugar crop in the world. It is with sugar cane produce almost all world consumption from sugar used in different sugar utilization. In arid land under the stress conditions and low available water and land use efficiency, intercropping system between field crops is very successful system to utilize the available resources to produce the highest benefit from the soil. In agriculture, several studies on intercropping have been carried out to evaluate potential agronomic and economic benefits (Hauggaard et al., 2001). Sugar beet root yields and sucrose yield were maximum in lentil intercropping compared to cereals and oilseeds intercroppings. It is recommended that intercropping of sugar beet variety Kaweterma with lentil should be practiced for higher qualitative, quantitative and monetary benefits (Usmanikhail et al., 2012). In the arid land conditions, the interest in intercropping has increased in recent years (Connolly et al., 2001; Anil et al., 1998). The intercropping of legumes with sugar crops may also be a feasible alternative system to increase the crop productivity (Carruthers et al., 1998; Ofori and Stern, 1987). Values of land return ratio were greater than 1.00 in any intercropping system of sugar beet with wheat, barley, and faba bean, indicating an advantage of the intercropping patterns for land usage and yield gain (Salama et al., 2016). Intercropping sugar beet with $25 \mathrm{~cm}$ - onion maximized the growers income and reduced insect pest infestations (Badawy and Shalaby, 2015). Farghaly et al., (2003) reported that yield of sugar beet has been reduced by intercropping with onion or faba bean compared to sole sugar beet. However, sugar beet intercropped with coriander gave a better performance to get interim benefit from the same area (Azad and Alam, 2004). 
Intercropping can improve soil quality and ecological microclimate and enhances crop productivity ( $\mathrm{Li}$ et al., 1999). Intercropping sugar beet with lentil gave the highest monetary benefits compared to the sole sugar beet, or other intercropping systems. In addition, the highest values of land equivalent ratio were observed when sugar beet was intercropped with onion, while the least were found when sugar beet was intercropped with faba bean (Farghaly et al., 2003). Intercropping faba been with sugar beet on different ridge width significantly affected sugar beet yield and yield components. (Hamdany and Aassar, 2017). Sugar beet genotypes differed significantly in root length, root fresh weight, root yield, and sucrose content (Enan et al., 2009, Mohamed et al., 2012, Mohamed and Yasin, 2013 and Mekdad and El-Sherif, 2016). Significance differences in crown tissue production and development rate may cause quality differences between sugar beet genotypes (Halvorson et al., 1978, Halvorson and Hartman, 1980 and Al-Sayed et al., 2012).

This study was conducted to investigate behavior of three sugar beet diverse genotypes including one monogerm cultivar from Belgium, one polygerm cultivar from Egypt and the third is polygerm cultivar from Syria under different intercropping systems with Saudi local clover cultivar under the arid land conditions.

\section{Materials and Methods}

This research was conducted during 2016/2017 and 2017/2018 seasons in the Agricultural Research Station, King Abdulaziz University at Hada Al-Sham region, Saudi Arabia. Three sugar beet cultivars from different regions were tested under 3 intercropping systems between sugar beet and Al-Hassawi local clover cultivar. Split plot design with 4 replicates was used in the two seasons. The main plot treatments were the 3 intercropping systems: 1 row sugar beet: 2 rows clover (1S: 2C), 1 sugar beet: 3 rows clover (1S: 3C), besides the sugar beet sole (So). Sub plots were occupied by 3 sugar beet cultivars: Farida polygerm cultivar from Egypt, Dita monogerm cultivar from Belgium and Heros polygerm cultivar from Syria. The sub plot consisted of 10 rows with $40 \mathrm{~cm}$ between each 2 rows and $30 \mathrm{~cm}$ between hills with one plant in each hill. Surface drip irrigation system was used and the dripper lines was installed with $40 \mathrm{~cm}$ between two adjacent dripper lines while the distance between drippers is $30 \mathrm{~cm}$. The type of the dripper line is RAIN BIRD LD- 06- 12-1000 Landscape drip 0.6 G/h@12". Inlet pressure on each tape was about 1.5 bars. The system uses 125-micron disk filter. Planting dates were 12 November and 20 October in the first and second season, respectively the common cultural practices were done according to ElNakhlawy and Ghandorah, 2009. At harvesting root length $(\mathrm{mm})$, root diameter $(\mathrm{mm})$, fresh root yield /ha $(\mathrm{t})$, dry root yield /ha (t) and sucrose yield/ha (t). Sucrose yield/ha was calculated by multiply sucrose content $(\%)$ by dry root yield/ha. Sucrose (\%) was measured using the Polarimetry method (A.O.A.C., 2006). Total chlorophyll content of leaves was measured at 55 days sugar beet age. Representative sugar beet leaves samples/sub plot were collected to determine total chlorophyll content. The total chlorophyll of sugar beet leaves were extracted from the fresh leaves of each sample by aceton $(80 \%)$. The spectrophotometer readings of the samples were measured using Spectrophotometer (Spectrophotometer Model 6120 , perkin-Elmer) at wave length $663 \mathrm{~nm}$. The equations of Jayarman (1988) were used to calculate the total chlorophyll concentrations $(\mathrm{mg} / \mathrm{g})$ in the leaves. 


\section{Statistical Analysis}

The obtained data of the experiment in the two seasons was statistically analyzed through analysis of variance procedures (ANOVA) then revised least significance difference (RLSD) test was used to compare between the treatment means after applying the statistical analysis assumptions according to El-Nakhlawy (2010) using SAS (2006).

\section{Results}

\subsection{Effect of Intercropping Systems}

\subsubsection{Root length}

The obtained results of root length under the effect of the three intercropping systems in the 2 seasons (Table 1) showed insignificant differences between the systems of 1sugar beet: 2 clover and 1sugar beet : 3 clover, but they significantly different from the sugar beet root length under the sole plantation. Root length ranged from $210.21 \mathrm{~mm}$ to $202.91 \mathrm{~mm}$ in the first season and from $216.43 \mathrm{~mm}$ to $207.01 \mathrm{~mm}$ in the second season.

\subsubsection{Root diameter}

The response of root diameter to the treatments of intercropping was opposite to the root length. The highest root diameter values were detected from the sugar beet sole and significantly different from the (1S: $2 \mathrm{C})$ or (1S: 3C) intercropping systems without significant differences between these last 2 intercropping systems in the 2 seasons. Root diameter of sugar beet as sole plantation in the $1^{\text {st }}$ and $2^{\text {nd }}$ seasons were $91.23 \mathrm{~mm}$ and 122.86 $\mathrm{mm}$, respectively while under the 2 intercropping systems (1S: 2C) and (1S: 3C) were around $83 \mathrm{~mm}$ and $119 \mathrm{~mm}$ as average of the 2 seasons, respectively (Table 1).

\subsubsection{Fresh root yield /ha}

The statistical comparisons between the means of fresh root yield /ha in each seasons (Table1) showed that the (1S: $2 \mathrm{C})$ and $(1 \mathrm{~S}$ : 3C) intercropping systems produced the highest fresh root yield /ha without significant difference and they dominated over the sole plantation. Fresh root yield /ha ranged from $61.50 \mathrm{t}$ to60.50 $\mathrm{t}$ in the first season and from $106.39 \mathrm{t}$ to $104.13 \mathrm{t} / \mathrm{ha}$ in the second season.

\subsubsection{Dry root yield/ha}

The presented data of dry root yield /ha under the intercropping systems (Table 2) showed similar trend as the fresh root yield/ha. No significant differences were found between the (1S: 2C) and (1S: 3C) intercropping systems but they significantly dominated over the sugar beet sole in both seasons. Dry root yield /ha ranged from $19.55 \mathrm{t} / \mathrm{ha}$ to $16.89 \mathrm{t} / \mathrm{ha}$ in $1^{\text {st }}$ season and from $37.13 \mathrm{t} /$ ha to $35.11 \mathrm{t} / \mathrm{ha}$ in the $2^{\text {nd }}$ season.

\subsubsection{Total chlorophyll content of leaves}

The intercropping system (1S: 2C) was the highest in the total chlorophyll content of sugar beet leaves $(2.55 \mathrm{mg} / \mathrm{g}$ and $3.01 \mathrm{mg} / \mathrm{g}$ in both seasons, respectively) and significantly different from (1S: 3C) system and sugar beet sole in both seasons. No significant differences were showed between the (1S: 3C) and sugar beet sole in both seasons.

\subsubsection{Sucrose yield/ha}

As shown in Table 2, the 2 intercropping systems (1S: 2C) and (1S: 3C) significantly similar in sucrose yield and significantly more than the sugar beet sole in the 2 seasons. Sucrose yield ranged from $3.3 \mathrm{t} / \mathrm{ha}-2.57 \mathrm{t} / \mathrm{ha}$ in the first season and $6.43 \mathrm{t} / \mathrm{ha}$ to $5.91 \mathrm{t} / \mathrm{ha}$ in the second season. 
Table 1. Means of root length $(\mathrm{mm})$, root diameter $(\mathrm{mm})$ and fresh root yield /ha $(\mathrm{t})$ of sugar beet under the effect of intercropping systems during 2016/2017 and 2017/2018 seasons.

\begin{tabular}{|c|c|c|c|c|c|c|}
\hline \multirow{3}{*}{$\begin{array}{l}\text { Intercropping } \\
\text { System }\end{array}$} & \multicolumn{6}{|c|}{ Means } \\
\hline & \multicolumn{2}{|c|}{$\begin{array}{l}\text { Root length } \\
\text { (mm) }\end{array}$} & \multicolumn{2}{|c|}{$\begin{array}{l}\text { Root diameter } \\
(\mathbf{m m})\end{array}$} & \multicolumn{2}{|c|}{$\begin{array}{l}\text { Fresh root yield/ha } \\
\text { (t) }\end{array}$} \\
\hline & $2016 / 17$ & $2017 / 18$ & $2016 / 17$ & $2017 / 18$ & $2016 / 17$ & $2017 / 18$ \\
\hline 1 sugar : 3 clover & $210.21 \mathrm{a}^{*}$ & $216.43 \mathrm{a}$ & $82.14 \mathrm{~b}$ & $118.61 \mathrm{~b}$ & $62.52 \mathrm{a}$ & $108.77 \mathrm{a}$ \\
\hline 1 sugar : 2 clover & $207.06 \mathrm{a}$ & $212.04 \mathrm{a}$ & $83.62 \mathrm{~b}$ & $119.16 \mathrm{~b}$ & $61.49 \mathrm{a}$ & $106.39 \mathrm{a}$ \\
\hline Sugar beet sole & $202.91 \mathrm{~b}$ & $207.01 \mathrm{~b}$ & $91.23 \mathrm{a}$ & $122.86 \mathrm{a}$ & $60.50 \mathrm{~b}$ & $104.13 \mathrm{~b}$ \\
\hline RLSD (0.05) & 3.37 & 6.40 & 2.11 & 1.78 & 1.42 & 2.45 \\
\hline
\end{tabular}

*Means of each trait under the main factor treatments followed by the same letter are not significantly different according to RLSD at $\mathrm{p} \leq .0 .05$.

Table 2. Means of dry root yield ( $\mathrm{t} / \mathrm{ha})$, total chlorophyll $(\mathrm{mg} / \mathrm{g})$ and sucrose $y i e l d / \mathrm{ha}(\mathrm{t})$ of sugar beet under the effect of intercropping systems during 2016/2017 and 2017/2018 seasons.

\begin{tabular}{|c|c|c|c|c|c|c|}
\hline \multirow{3}{*}{$\begin{array}{l}\text { Intercropping } \\
\text { Systems }\end{array}$} & \multicolumn{6}{|c|}{ Means } \\
\hline & \multicolumn{2}{|c|}{$\begin{array}{l}\text { Dry root yield/ha } \\
\text { (t) }\end{array}$} & \multicolumn{2}{|c|}{$\begin{array}{l}\text { Total chlorophyll } \\
\text { (mg/g) }\end{array}$} & \multicolumn{2}{|c|}{$\begin{array}{c}\text { Sucrose yield/ha } \\
\text { (t) }\end{array}$} \\
\hline & $2016 / 17$ & $2017 / 18$ & $2016 / 17$ & $2016 / 17$ & $2016 / 17$ & $2017 / 18$ \\
\hline 1 sugar : 2 clover & $18.43 \mathrm{a}^{*}$ & $36.65 \mathrm{a}$ & $2.53 \mathrm{a}$ & $3.01 \mathrm{a}$ & $3.12 \mathrm{a}$ & $6.21 \mathrm{a}$ \\
\hline 1 sugar : 3 clover & $19.55 \mathrm{a}$ & $37.13 \mathrm{a}$ & $2.46 \mathrm{~b}$ & $2.84 \mathrm{~b}$ & $3.31 \mathrm{a}$ & $6.43 \mathrm{a}$ \\
\hline Sugar beet sole & $16.89 \mathrm{~b}$ & $35.11 \mathrm{~b}$ & $2.44 \mathrm{~b}$ & $2.87 \mathrm{~b}$ & $2.57 \mathrm{~b}$ & $5.91 \mathrm{~b}$ \\
\hline RLSD (0.05) & 1.18 & 0.91 & 0.03 & 0.05 & 0.21 & 0.26 \\
\hline
\end{tabular}

*Means of each trait under the main factor treatments followed by the same letter are not significantly different according to RLSD at $\mathrm{p} \leq .0 .05$.

\subsection{Effect of Sugar Beet Cultivars}

According to the sugar beet cultivars genetic makeup and their interaction with the environment conditions, the data of the 3 studied sugar beet cultivars were expressed on these genetic, environment and genetic $\times$ environment interaction.

\subsubsection{Root length/ha}

Farida cv. had the longest roots and significantly more than the other 2 cultivars in both seasons. No significant differences were showed between Dita and Heros cv in both seasons. Root length means of Frida, Heros and Dita cultivars were 228.69, 204.8 and $208.69 \mathrm{~mm}$, respectively in the first season and $215.09,210$, and $209.32 \mathrm{~mm}$, respectively in the second season as shown in Table 3.

\subsubsection{Root diameter}

As shown in Table 3, Farida cv was the highest in root diameter $\left(92.83 \mathrm{~mm}\right.$ in the $1^{\text {st }}$ season and $118.55 \mathrm{~mm}$ in the $2^{\text {nd }}$ season) followed by Dita cv then Heros cv was the lowest in root diameter $(70.72 \mathrm{~mm}$ and 113.42 $\mathrm{mm}$ in both seasons, respectively).

\subsubsection{Fresh root yield/ha}

The highest fresh root yield/ha was produced from Frida and significantly was over the two cultivars in both seasons. Farida fresh root yield /ha in the $1^{\text {st }}$ and $2^{\text {nd }}$ season were $60.62 \mathrm{t} / \mathrm{ha}$ and $97.02 \mathrm{t} / \mathrm{ha}$, respectively. Heros produced $57.26 \mathrm{t} / \mathrm{ha}$ and $64.55 \mathrm{t} / \mathrm{ha}$ and Dita cv produced $58.62 \mathrm{t} / \mathrm{ha}$ and $90.72 \mathrm{t} / \mathrm{ha}$ in both seasons, respectively (Table 3 ).

\subsubsection{Dry root yield /ha}

As for fresh root yield /ha, dry root yield /ha responded to the genotype, where Farida cv was the highest in both season $(22.69 \mathrm{t} / \mathrm{ha}$ in the $1^{\text {st }}$ season and $37.94 \mathrm{t} / \mathrm{ha}$ in the $2^{\text {nd }}$ season) followed by Dita cv (18.24t/ha and $34.69 \mathrm{t} / \mathrm{ha}$ in the $1^{\text {st }}$ and $2^{\text {nd }}$ seasons, respectively). Heros 
produced the lowest dry root yield /ha in both seasons (Table 4).

\subsubsection{Total chlorophyll content}

The obtained results of total chlorophyll content of the leaves in the three cultivars (Table 4) showed that Farida cv was the highest followed by Dita cv while Heros was the lowest. No significant differences were found between Farida cv and Dita cv but they significantly dominated over Heros cv in both seasons. Total chlorophyll in Farida, Dita, and Heros cultivars were 2.67, 2.59 and $2.17 \mathrm{mg} / \mathrm{g}$, respectively in the first season, and in the second season were $3.14,3.15$ and $2.43 \mathrm{mg} / \mathrm{g}$, respectively (Table 4).

\subsubsection{Sucrose yield/ha}

Significant differences were found between the 3 cultivars for sucrose yield/ha in the 2 seasons. Farida $\mathrm{cv}$ produced the highest sucrose yield /ha in the $1^{\text {st }}$ season $(4.06 \mathrm{t} / \mathrm{ha})$ and $2^{\text {sd }}$ season $(6.97 \mathrm{t} / \mathrm{ha}$ ) followed by Dita cv (3.43 t/ha and $6.72 \mathrm{t} / \mathrm{ha}$ ) then Heros cv (2.12 $\mathrm{t} / \mathrm{ha}, 3.35 \mathrm{t} / \mathrm{ha})$ in the $1^{\text {st }}$ and $2^{\text {nd }}$ season, respectively as shown in Table 4.

\subsection{Effect of the Interaction between Intercropping Systems and Sugar Beet Cultivars}

\subsubsection{Root length}

Significant differences were showed for the root length under the 9 interaction treatments in both studied seasons. The tallest root were found in Farida cv under the (1S:2C) intercropping system with values of 228.43 $\mathrm{mm}$ and Dita cv under (1S:3C) intercropping system $(225.72 \mathrm{~mm})$ in the first season .The shortest root length means were detected from the sugar beet Dita and Heros cv sole plantations $(195.48 \mathrm{~mm}$ and $195.83 \mathrm{~mm}$, respectively ). In the second season the highest root length means were showed from Farida cv under 1:3system $(217.68 \mathrm{~mm})$, Heros cv under (1S:3C) system $(217.76 \mathrm{~mm})$ without significant differences from Farida cv and Dita cv under (1S:2C) intercropping system with values of $215.91 \mathrm{~mm}$ and $214.86 \mathrm{~mm}$, respectively. The shortest roots were found in Heros cv and Dita cv as sole plantations (205.26 $\mathrm{mm}$ and $204.08 \mathrm{~mm}$, respectively) as shown in Table 5.

\subsubsection{Root diameter}

The presented data in Table 5 showed that Farida cv was the highest in root diameter under any intercropping systems and no significant differences were found between root diameter means of Farida under the 3 intercropping systems in each season. Root diameter ranged from $89.25 \mathrm{~mm}$ to $67.96 \mathrm{~mm}$ in the first season and from $119.03 \mathrm{~mm}$ to $100.36 \mathrm{~mm}$ in the second season. Heros cv under the system of (1S : 3C) in the first season $(67.96 \mathrm{~mm})$ and $(100.36 \mathrm{~mm})$ under $(1 \mathrm{~S}: 3 \mathrm{C})$ also in the second season.

\subsubsection{Fresh root yield/ha}

The statistical comparisons of fresh root yield /ha under the intercropping between 3 sugar beet cultivars and 3 intercropping systems, showed that Farida cv was the highest in fresh root yield/ha under any intercropping system and significantly different from the other interaction treatments. Dita cv under the intercropping system of $(1 \mathrm{~S}: 2 \mathrm{C})$ in the first season, the system of (1S:2C), and sugar beet sole occupied the $2^{\text {nd }}$ rank in fresh root yield/ha. The lowest fresh root yield/ha produced from Heros $\mathrm{cV}$ under the systems of $(1 \mathrm{~S}: 2 \mathrm{C})$ and $(1 \mathrm{~S}: 3 \mathrm{C})$ in the $1^{\text {st }}$ and $2^{\text {nd }}$ seasons, respectively (Table 5 ).

\subsubsection{Dry root yield/ha}

Similar response as the fresh root yield/ha, dry root yield/ha responded to the interaction between intercropping system and cultivar. Farida cv under sole plantation produced the highest dry yield in the first and second seasons (24.27 t/ha and $39.14 \mathrm{t} / \mathrm{ha}$ ) respectively followed by Farida $\mathrm{cv}$ under 
(1S:2C) intercropping system. Significant differences were found between Heros cv under (1S:2C) and (1S: 3C) intercropping systems and the other 2 cvs under intercropping systems in both seasons. Generally, Heros cv was the lowest cultivar under all intercropping systems compared with the other interactions treatments (Table 6).

\subsubsection{Total chlorophyll content}

The obtained results (Table 6) showed that Farida cv under the (1S:3C) system had the highest chlorophyll content in both seasons (2.68 and $3.3 \mathrm{mg} / \mathrm{g}$, respectively). Heros $\mathrm{cv}$ as a sole plantation was the lowest in total chlorophyll content $(2.15$ and $2.92 \mathrm{mg} / \mathrm{g}$ in both seasons, respectively). Dita cv under the intercropping systems of $(1 \mathrm{~S}: 2 \mathrm{C})$ or $(1 \mathrm{~S}: 3 \mathrm{C})$ followed Farida cv under the different intercropping systems in total chlorophyll in the 2 seasons.

\subsubsection{Sucrose yield/ha}

As shown in Table 6, Farida cv under the (1S:3C) intercropping system produced the highest sucrose yield/ha in the $1^{\text {st }}$ and $2^{\text {nd }}$ seasons (4.45 t/ha and $7.04 \mathrm{t} / \mathrm{ha}$, respectively) followed by Farida cv under (1S:2C) system (4.32 t/ha and $7.02 \mathrm{t} /$ ha in both seasons, respectively). Dita cv under (1S:3C) system and Dita cv under $(1 \mathrm{~S}: 2 \mathrm{C})$ system occupied the $2^{\text {nd }}$ rank with significant difference from Farida cv under (1S:3C) system. Heros cv under the 3 intercropping systems were significantly the lowest in sucrose yield /ha compared with the other interaction treatments.

Table 5. Means of root length $(\mathrm{mm})$, root diameter $(\mathrm{mm})$ and Fresh root yield $(\mathrm{t})$ under the effect of the interaction between intercropping systems and sugar beet cultivars during 2016/2017 and 2017/2018 seasons.

\begin{tabular}{|c|c|c|c|c|c|c|c|}
\hline \multirow{3}{*}{$\begin{array}{c}\text { Intercropping } \\
\text { system }\end{array}$} & \multirow{3}{*}{ Cultivar } & \multicolumn{6}{|c|}{ Means } \\
\hline & & \multicolumn{2}{|c|}{$\begin{array}{l}\text { Root Length } \\
(\mathrm{mm})\end{array}$} & \multicolumn{2}{|c|}{$\begin{array}{l}\text { Root diameter } \\
(\mathrm{mm})\end{array}$} & \multicolumn{2}{|c|}{$\begin{array}{c}\text { Fresh root yield } \\
(\mathrm{t} / \mathrm{ha})\end{array}$} \\
\hline & & $2016 / 17$ & $2017 / 18$ & $2016 / 17$ & $2016 / 17$ & $2017 / 18$ & $2016 / 17$ \\
\hline \multirow{3}{*}{ 1sugar:2clover } & Dita & 207.87 & 214.86 & 83.62 & 119.13 & 58.65 & 91.56 \\
\hline & Heros & 203.88 & 208.35 & 70.73 & 115.57 & 54.45 & 65.72 \\
\hline & Farida & 228.43 & 215.91 & 86.07 & 119.03 & 68.29 & 97.42 \\
\hline \multirow{3}{*}{ 1sugar:3clover } & Dita & 225.72 & 207.85 & 79.16 & 104.72 & 60.93 & 88.26 \\
\hline & Heros & 214.77 & 217.76 & 67.96 & 100.36 & 59.13 & 59.65 \\
\hline & Farida & 212.17 & 217.68 & 89.25 & 118.39 & 67.5 & 94.4 \\
\hline \multirow{3}{*}{ Sugar beet sole } & Dita & 195.48 & 205.26 & 85.17 & 114.58 & 58.07 & 92.34 \\
\hline & Heros & 195.83 & 204.08 & 73.88 & 112.66 & 56.28 & 67.2 \\
\hline & Farida & 215.43 & 211.68 & 88.18 & 118.25 & 70.08 & 99.25 \\
\hline \multicolumn{2}{|c|}{ RLSD (0.05) } & 5.03 & 8.75 & 4.40 & 2.78 & 2.20 & 3.60 \\
\hline
\end{tabular}

Table 6. Means of Dry root yield(ha), Total chlorophyll $(\mathrm{mg} / \mathrm{g})$, and Sucrose yield ha(t) and under the effect of the interaction between intercropping systems and sugar beet cultivars during 2016/2017 and 2017/2018 seasons.

\begin{tabular}{|c|c|c|c|c|c|c|c|}
\hline \multirow{3}{*}{$\begin{array}{l}\text { Intercropping } \\
\text { system }\end{array}$} & \multirow{3}{*}{ Cultivar } & \multicolumn{6}{|c|}{ Means } \\
\hline & & \multicolumn{2}{|c|}{$\begin{array}{l}\text { Dry root yield } \\
\text { (t/ha) }\end{array}$} & \multicolumn{2}{|c|}{$\begin{array}{l}\text { Total chlorophyll } \\
\text { (mg/g) }\end{array}$} & \multicolumn{2}{|c|}{$\begin{array}{c}\text { Sucrose yield/ ha } \\
\text { (t) }\end{array}$} \\
\hline & & $2016 / 17$ & $2017 / 18$ & $2016 / 17$ & $2016 / 17$ & $2017 / 18$ & $2016 / 17$ \\
\hline \multirow{3}{*}{ 1sugar:2clover } & Dita & 17.92 & 34.78 & 2.67 & 3.16 & 3.35 & 6.68 \\
\hline & Heros & 17.66 & 25.57 & 2.19 & 2.43 & 2.26 & 3.39 \\
\hline & Farida & 22.72 & 38.36 & 2.72 & 3.04 & 4.32 & 7.02 \\
\hline \multirow{3}{*}{ 1sugar:3clover } & Dita & 20.12 & 34.66 & 2.54 & 3.27 & 3.88 & 6.77 \\
\hline & Heros & 18.44 & 23.59 & 2.16 & 2.47 & 2.44 & 3.22 \\
\hline & Farida & 21.09 & 36.31 & 2.68 & 3.3 & 4.45 & 7.04 \\
\hline \multirow{3}{*}{ Sugar beet sole } & Dita & 17.75 & 34.62 & 2.54 & 3.02 & 3.06 & 6.56 \\
\hline & Heros & 16.67 & 26.19 & 2.15 & 2.42 & 1.68 & 3.37 \\
\hline & Farida & 24.27 & 39.14 & 2.62 & 3.08 & 4.05 & 6.80 \\
\hline \multicolumn{2}{|c|}{ RLSD $(0.05)$} & 1.20 & 0.86 & 0.15 & 0.08 & 0.30 & 0.26 \\
\hline
\end{tabular}




\section{Discussions}

At first the big differences between the results of the two seasons, may be due to the effects of the environmental conditions during the 2 seasons, which resulted from the different planting dates in the 2 seasons. The second season was earlier in planting date with 22 days than the first season. In the second season, plants grow in long season under the not long photoperiod than the first season. The long growing season enhanced the photosynthesis and nutrients accumulation, which reflected into high yield and yield components in the second season more than the first season (Mohamed and Yasin, 2013, Enan et al., 2009). The superiority of Farida cultivar over Dita and Heros cultivars in root yield, yield components, sucrose yield and total chlorophyll might been due to the genetic makeup of the 3 cultivars. Farida polygerm cultivar had genes of high yield potential and yield components more than the other 2 cultivars. In addition, Farida cv was Egyptian cultivar and adopted to the environmental conditions nearly like the conditions of the winter season of Jeddah, while and although Dita cv is a monogerm cv but its Belgium cv and produced under the cold conditions, accordingly it affected by the interaction between genetic makeup and Jeddah environment. Also, Heros cv was a Syrian cv and was cultivated under low temperature in Syria less than the Jeddah temperature besides the genetic makeup of this cultivar which reflected on its performance under the Jeddah conditions. (Enan et al., 2009, Mohamed et al.,2012, Mohammed and Yasin, 2013 and Mekdad and EL-Sherif, 2016). In addition, the significance differences between the genotypes in chlorophyll content and development rate may cause sucrose content differences (Halvorson and Hartman, 1980 and AL-Sayed et al., 2012). The good sugar beet performance and dominating under the intercropping with clover with (1S: $2 \mathrm{C})$ or (1S: 3C) systems more than the sugar beet sole plantation may be due to the positive effects of the intercropping with the legume crop in improving of soil nutrients profile, soil texture, soil water holding capacity, ecological micro climate and enhancing crop productivity (Li et al., 1999). Intercropping sugar beet with clover increase the nutrients in the soil through the analysis of clover roots and plant residuals after cutting of clover plants (Salama et al., 2016 and Carruthers et al., 1998).

\section{Conclusions}

The obtained results of this study showed that sugar beet crop intercropped with clover in 1 sugar beet: 3 clover and 1 sugar beet: 2 clover significantly increased sugar beet root yield/ha and sucrose yield/ha compared with sugar beet sole. Farida cultivar was the highest cultivar in root yield/ha, sucrose yield/ha and total chlorophyll content. The best sugar beet root yield and sucrose yield/ha were produced from Farida cultivar under the 1 sugar beet: 3 clover intercropping system.

\section{References}

A.O.A.C. (2006). Association of Official Agricultural Chemists. Official Methods of Analysis of the AOAC International, 17th, Ed. Washington, D.C., USA.

Azad, M.A.K. and Alam, M.J. (2004). Popularizing of sugarcane based intercropping systems in Non Millzone, J. Agron., 3(3): 159-161.

Anil, L., Park, J., Phipps, R.H. and Miller, F.A. (1998). Temperate intercropping of cereals for forage: a review of the potential for growth and utilization with particular reference to the UK, Grass and Forage Sci., 53: 301-317.

Badawy, S. A. and Shalaby, G.A. (2015). Effect of intercropping of sugar beet with onion and garlic on insect infestation, sugar beet yield and economic, J. Plant Production, Mansoura Univ., 6 (6): 903-914.

Carruthers, K., Fe, Q., Clauthier, D. and Smith, D.L. (1998). Intercropping corn with soybean, Lupin and for ages, weed control by inter row cultivation, Eur. J. Agron., 7: 114-127.

Connolly, J., Goma, H.C. and Rahim, K. (2001). The information content of indicators in intercropping 
research. Agriculture, Ecosystems and Environ., 87: 191207.

El-Nakhlawy, F. S. (2010). Statistical Design and Analysis in Scientific Research. Sci. Pub Center, King Abdulaziz University, Saudi Arabia.

EL-Nakhlawy, F. S. and Ghandorah, M. (2009). Practical Practices of Field Crop Production. Sci. Pub.Center, King Abdulaziz University, Jeddah, Saudi Arabia.

Enan, S. A. A. M., El- Sheikh, S. R. E. and Khaled, K. A. M. (2009). Evaluation of some sugar beet varieties under different levels of $\mathrm{N}$ and Mo fertilization. J. Biol. Chem. Environ., Sci., 4 (1): 345-362.

Farghaly, B.S., Zohry, A.A. and Bassal, A.A. (2003). Crops management for intercropping sugar beet with some essential crops to maximize area unit productivity. Journal of Agricultural Sciences, Mansoura Univ., 28: 5183-5199.

Halvorson, A.D. and Hartman, G.P. (1980). Response of several sugarbeet cultivars to $\mathrm{N}$ fertilization: yield and crown tissue production. Agron. J., 72: 665-669.

Halvorson, A.D., Hartman, G.P., Cole, D.F., Haby, V.A. and Baldridge, D.E. (1978). Effect of $\mathrm{N}$ fertilization on sugar beet crown tissue production and processing quality. Agron. J., 70: 876-880.

Hussein, A.M., Usama, A.A., Hazem, S.M. and Hayam , F.S. (2012). Effect of harvest dates on yield and quality of sugar beet varieties. Australian Journal of Basic and Applied Sciences, 6(9): 525-529.

Hamdany, M.K.H. and EL-Aassar, M.R. (2017). Effect of intercropping three faba been varieties with sugar beet plants on piercing sucking insect pests and associated natural enemies under ridge space seedling rates in relation crop yield, Egypt. Acad. J. Biolog. Sci., 10(6): $57-$ 77.

Hauggaard-Nielsen, H. and Jensen, E.S. (2001). Evaluating pea and barley cultivars for complementarity in intercropping at different levels of soil $\mathrm{N}$ availability. Field Crops Research, 72: 185-196.
Jayaraman J. (1988). Laboratory Manual in Biochemistry. Third Edition, Wiley Eastern Ltd., New York, USA.

Li, L., Yang, S.C., Li, X.L., Zhang, F.S. and Christie, P. (1999). Interspecific complementary and competitive interactions between intercropped maize and faba bean. Plant Soil, 212: 105-114.

Mohamed, K. El., Mohamed, H. Y. and Abdel Fatah, E.M. (2012) .Effect of nitrogen sources fertilization and boron foliar application on growth, quality and productivity of some sugar beet varieties. J. Biol. Chem. Environ. Sci., 7(4): 177-192.

Mohamed, Y.H. and Yasin, M.A.T. (2013). Response of some sugar beet varieties to harvesting dates and foliar application of some boron and zinc in sandy soils. Egypt. J. Agron., 35 (2): 227-252.

Mekdad, A.A. and EL-Sherif, A.M. (2016). Performance of two sugar beet varieties under fertilization with potassium and foliar spraying with micro nutrients. Egypt. J. Agron., 38 (2): 189-207.

Ofori, F. and Stern, W.R. (1987). Cereal-legume intercropping systems. Adv. Agron., 41: 41-90.

Salama, H. S., Dina El-S, E. K. and Nawar, A. I. (2016). Additive Intercropping of Wheat, Barley, and Faba Bean with Sugar Beet: Impact on Yield, Quality and Land Use Efficiency. Egypt. J. Agron., 38 (3): 413-430.

SAS Institute (2006). SAS users guide: Statistics. Version 8. SAS Inst., Cary, NC., USA.

Schrepel, K. and Hoffmann, C. (2013). Calculation of invert sugar content based on the glucose content of sugar beet. Sugar Industry/Zuckerind, 138: 463-470.

Usmanikhail, M. U., Tunio, G.H., Oad, F.C., Ulhassan, S.W., Chachar, Q.D., Khanzad, M. A. and Gandahi, A.W. (2012). Agronomic and economic effect of intercropping sugar beet with oil and lentil. Pak. J. Bot., 44(6):1983-1988.. 
أداء أصناف بنجر السكر تحت التحميل مع البرسيم في ظروف المناطق الجافة غسان حيدر إدريس، و فتحي سعد النخلاوي، و صالح محمود إسماعيل قسم زراعة المناطق الجافة -كلية الأرصاد والبيئة وزراعة المناطق الجافة، جامعة الملك عبد العزيز، جلة، المملكة العربية السعودية

ghassanedrees983@gmail.com

المستخلص. أجريت هذه الدراسة بمحطة الأبحاث الزراعية بها الثام التابعة لجامعة الملك عبدالعزيز لتقييم أداء ثلاثة أصناف بنجر سكر، هي: أصناف فريدة (متعدد الأجنة-مصري)، لأهنة وديتا (وحيد الجنين-بلجيكي) وهيروس (متعدد الأجنةسوري) تحت ثلاثة نظم من التحميل،

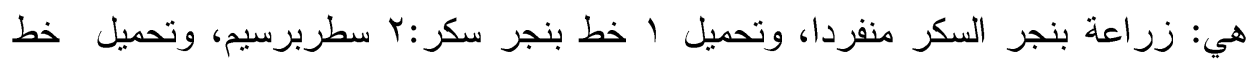

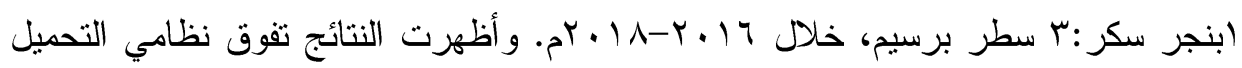
على الزراعة المنفردة، وكذلك تفوق الصنف فريدة على الصنفين الآخرين في محصول

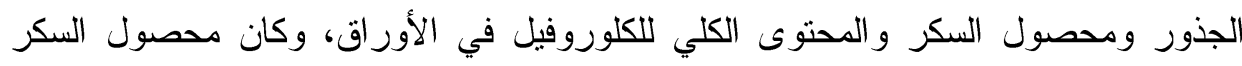

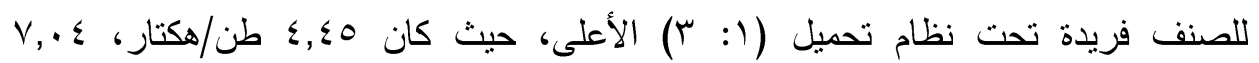
طن/هكتار في الموسمين الأول والثاني علي الترتيب. الكلمات الدفتاحبة: الكلوروفيل، الأصناف، التحميل، السكر، بنجر السكر. 
